\title{
Advances in the breeding of oats \\ Comparative trials with historical varieties in $1977-87$
}

\author{
MATTI REKUNEN \\ Hankkija Plant Breeding Institute \\ SF-04300 Hyrylä, Finland
}

\begin{abstract}
From 1977 to 1987, variety trials were conducted at two test sites in order to determine the agronomic value of old oat varieties as compared to that of the varieties presently grown. The trial sites were located at two breeding stations of the Hankkija Plant Breeding Institute, those of Nikkilă $\left(61^{\circ} 33^{\prime} \mathrm{N}\right.$ latitude) and Anttila $\left(60^{\circ} 25^{\prime} \mathrm{N}\right.$ latitude). The variety trials were performed according to the methods of Partially Balanced Lattices, and the results and their summary were computed according to the Nearest Neighbour Analysis. Eleven oat varieties released by the Institute between 1921 and 1982 as well as the old native oat variety from Ylitornio and the American oat variety Wasa, released in the 1920s, were all tested simultaneously.

The materials are presented in Table 1, the test environment in Table 2. The main findings are shown in Tables $3 \& 4$ and in Figures $1-5$. The correlations between the age of the varieties and their characteristics are presented, in order of quality, in Table 5.

The field experiments showed that intense progress in breeding work is reflected as increased crop yield, shortening of the straw, improved strength of the straw, and decreased husk content. In the trials the crop yield of the newest variety, Hankkijan Vouti variety, averaged 51 per cent more than the Ylitornio land race variety. The mean improvement in these properties achieved in 1921-1982 by means of breeding work was: an increase in crop yield of approximately 40 per cent; shortening of the straw by roughly 20 per cent; reduction of the tendency to lodging by about half; and lowering of the husk content by some 2 percentage points.

In contrast, no constant advances could be shown for the earliness at heading or ripening, the 1000 kernel weight, the hectolitre weight, the crude protein content or resistance to Barley Yellow Dwarf Virus (BYDV). The 1000 kernel weight and the hectolitre weight had risen from those of the local oat variety, whereafter development ceased to occur.

The study also investigated the ratio between genotype and environmental effects. In the experimental series, environmental factors had an effect on determining the time needed for ripening, the crude protein content, the length of the straw, the hectrolitre weight and crop yield that was at least five times greater than the effect of genotype. Genotype proved to have a stronger influence on the 1000 kernel weight, for which the variance component of genotype was threefold that of the environmental component. The heritability values in the experimental series ranged from 0.19 (for BYDV infection) to 0.77 (for time to heading).
\end{abstract}

Index words: oats, old varieties 


\section{Introduction}

\section{Starting-point and main objects of} the breeding of oats

Oats were grown extensively in Finland as early as the beginning of this century. At that time, the small grain size, low hectolitre weight, poor resistance to lodging and low yield of the local land races compared with foreign varieties grown contemporaneously, although being too late for our conditions, spurred us to start our own breeding work in Finland. When the Hankkija Plant Breeding Institute was established in 1913, the elimination of these drawbacks became the main object of the breeding work (SAULi 1920a, b, 1925a).

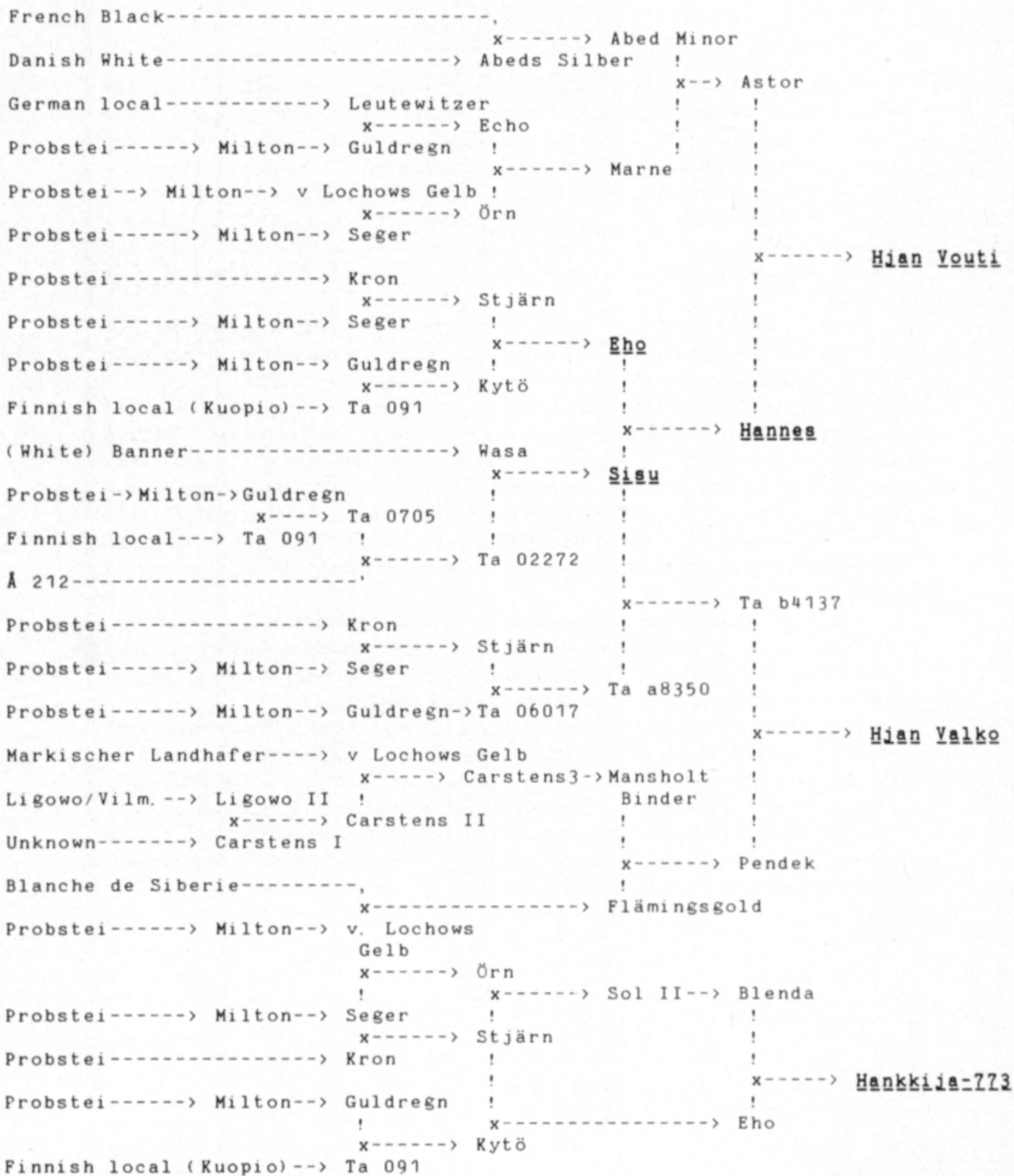


Because of Finland's northern location and its consequent severe climate, one of the most important targets of breeding spring cereals, and oats among them, is sufficient earliness. Many oat varieties bred elsewhere in Europe have proved to be too late to be cultivated in our country (SAULI 1920c, 1930a, KIVI 1963).

\section{Varieties released}

Since the beginning of the 1920s, the Hankkija Plant Breeding Institute has released al- together 16 oat varieties (Fig. 1), which are described briefly below.

The Institute's first oat variety was named Jalostettu maatiaiskaura (Bred Land Race of Oats), line No. 0144. It was released in 1921, and was a fairly early variety with dark brown grains. It was developed by the cross-breeding method, one of its parent cultivars being line No. 091-3, a selected land race collected in the Kuopio region (lat. $63^{\circ} \mathrm{N}$ ), and the other, Svalöf's Guldregn (SAuli 1920c, 1921b, 1925b).
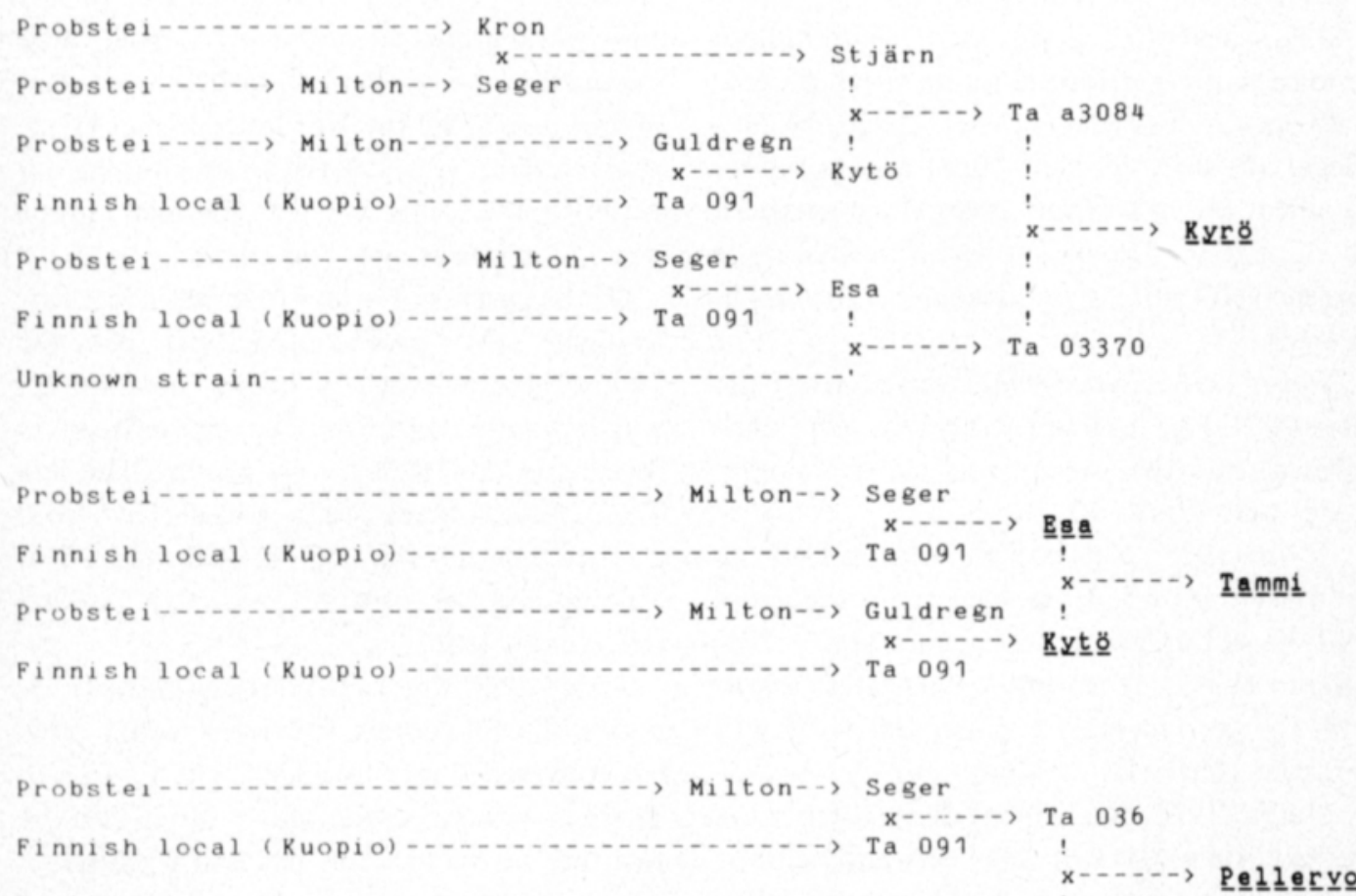

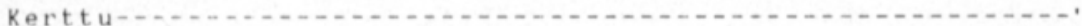

$\underline{P} \underline{\underline{e}} \underline{\underline{1}} \underline{\underline{e}} \underline{\mathrm{r}} \underline{\mathrm{v}} \underline{\mathrm{g}}$
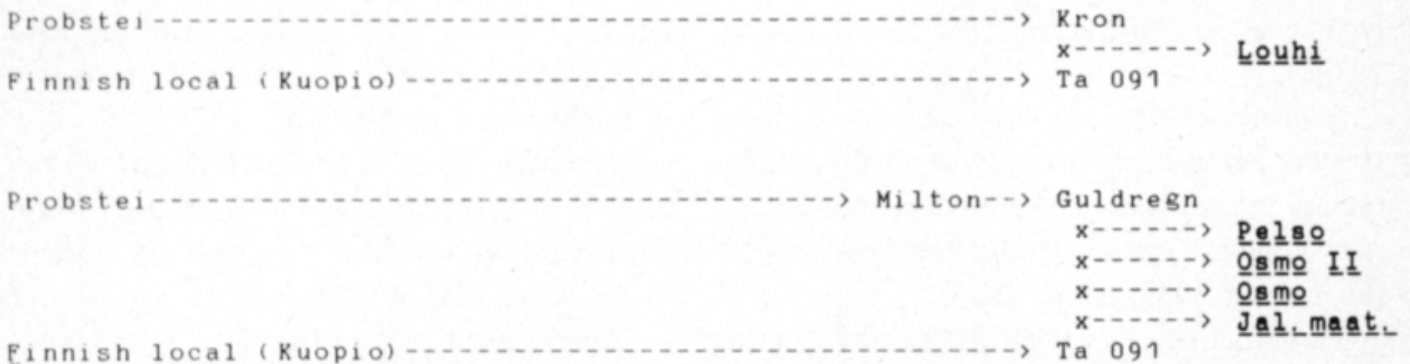

Fig. 1. The pedigree tree of varieties bred by the Hankkija Plant Breeding Institute (breeding stations Tammisto, Anttila and Nikkila). The varieties are presented from the youngest to the oldest one. 
The local land race No. 091-3 was a midearly variety with dark brown grains (SAULI 1920a). This line of local variety was used as one parent of altogether seven varieties released in the following years.

Osmo (1921, No. 0537) was a mid-early variety with dark brown grains, which also derived from the cross 091-3 x Guldregn (SAULI 1920c, 1921b, 1925b).

Osmo II (1922, No. 0693), like those above, had dark brown grains and belonged to the group of mid-early oat varieties. The variety derived from the cross 091-3 x Guldregn (SAuli 1920c, 1925b).

Esa (1922, 0644) derived from the cross 091-3 x Seger. Its grains were white-hulled, and the variety belonged to the group of midlate oat varieties (SAULi 1920c, 1921b, 1925b). Seger (Svalöf, Sweden 1908) was a whitegrained, rather late variety grown in southern Finland (SAUL1 1930a). It was cultivated quite extensively for two decades (HUTTUNEN 1946a).

Pelso (1925, No. 0993) derived from the cross 091-3 x Guldregn. Its grains were dark brown, and the variety was classed among early oats (SAULi 1925b, c).

Kytö (1925, No. 01108) belonged to the mid-early group. It derived from the cross 091-3 x Guldregn, and its grains were yellow (SAuli 1925b, c). Twenty years later, it was still the second most popular oat variety in Finland (HUTTUNEN 1946a).

Louhi (1928, No. 01555) derived from the cross Kron x 091-3. It was fairly early and its grains were dark brown (HUTTUNEN 1930, SAUli 1930b). Kron (Svalöf, Sweden 1914) was a late variety with white grains, which was hardly at all cultivated in Finland (SAULI 1930a).

Pellervo (1935, No. 01651) was a longstrawed, mid-late variety with white, highquality grains. It derived from a cross between the Finnish Kerttu oat and the line Ta 036 (Huttunen 1935, SAuli 1935).

Tammi (1938, No. 06587) derived from the cross Esa $x$ Kytö. Its grains were white, and the variety belonged to the group of early oats
(VAlle 1938). Owing to its earliness, it was still at the end of the 1950s the most popular oat variety grown in the northern parts of the oat cultivation area (HUTTUNEN 1960a).

Eho (1946, No. Ta a6595) derived from the cross Kytö x Stjärn. Eho was fairly early and white-grained (HuTTUNEN 1946b). Stjärn (Svalöf, Sweden 1927), in turn, derived from the cross Seger x Kron and was a rather late variety with white grains (SAULI 1930a). In the late 1950s, Eho was the most extensively cultivated oat variety in Central Finland (HutTunen 1960a).

Sisu (1948, No. Ta a6933) derived from the cross Wasa $x$ Ta 02272 . It was a late variety with white grains, which was reported to be the most high-yielding oat variety in its class of earliness in all the Nordic countries (HuTTUNEN 1950). Sisu was the most popular oat variety in the southern parts of Finland in the late 1950s (HUTTUNEN 1960a).

Of the parents of Sisu, Wasa was a late variety with white grains. It derived from the (White) Banner variety grown in Canada, which was marketed by the name Wasa in Sweden in the 1920s (SAuli 1930a). The line Ta 02272 had black grains and derived from a cross between the line $\AA 212$ developed in Finland and the Institute's own line Ta 0705 (HutTUNEN 1950).

Kyrö (1959, No. Ta 01406) was an early variety with white grains. It derived from a cross between two lines, Ta a3084 and Ta 03370. These lines were based, among others, on the Institute's own varieties Esa and Kytö (HuTTUNEN 1960b).

Hannes (1964, No. Ta b5794) belonged to the mid-early group. It had white grains and derived from a cross between Sisu and Eho (KIvı 1965). Hannes was cultivated extensively in the 1960s and 1970s.

Hankkija-773 (1973, No. Hja 30357) belonged to the mid-early group. It had white grains and derived from the cross Eho x Blenda (REKUNEN 1976b).

Hankkijan Valko (1976, No. Hja 31914) was released in 1976. It belongs to the midearly group and has good quality traits and 
white grains. The variety derives from a cross between Pendek and $\mathrm{Hja}$ 24137, which is a pedigree line of Sisu (REKUNEN 1980).

Hankkijan Vouti (1982, No. Hja 72801) also has white grains and is a mid-late, highyielding variety. It derives from a cross between Hannes and the Dutch Astor (REKUnEN 1985b).

\section{Progress of breeding}

The progress of breeding with Finnish varieties has been indirectly measured by KIVI (1963) through standard varieties, but only varieties topical at each time have been placed in the trials simultaneously. Varieties of different periods have not been investigated in simultaneous comparisons in our country. Therefore, a series of trials was established at the Hankkija Plant Breeding Institute in 1977. It included a considerable part of the oat varieties released during the Institute's activity, of which seed had been preserved.

In Germany, Aufhammer and Fischbeck (1964) investigated the cultivation traits of old barley and oat material found in the stone base of the Nuremberg City Theatre, in comparison with present varieties. The samples had been walled up in the foundation of the building during the construction work in 1832 and were found some 130 years later, when the theatre was being repaired. Efforts to produce descendants from part of the grains were successful, and the seed again was used to establish the comparative field trials.

\section{Material and methods}

For the purpose of comparing the progress in breeding work and reinvestigating the traits of old varieties, field trials were established at two of the Hankkija Plant Breeding Institute's breeding stations in 1977-87. Of the trial sites, Anttila is situated in a clay area near Finland's southern coast and Nikkilä in an inland hillocky silt area $150 \mathrm{~km}$ farther north.

The trials contained a major part of the Institute's old varieties and two other oat varieties, of which one was an old local variety of the river Tornio valley (lat. $66^{\circ} \mathrm{N}$ ) in northern Finland and the other the Wasa oat referred to above (Table 1).

The local variety in question had been collected as the Ylitornio land race at the beginning of this century. It was an early-maturing oat variety with dark brown grains and very wide panicles (SAULi 1921a, HutTUNEN 1930).

The Institute's newest varieties were included in the trial series and thus offered a chance for simultaneous comparison of varieties

Table 1. Oat varieties in field trials $1977-87$ at the Hankkija Plant Breeding Institute. The varieties are presented in order of their age.

\begin{tabular}{llcl}
\hline $\begin{array}{l}\text { Age } \\
\text { rank }\end{array}$ & $\begin{array}{l}\text { Variety } \\
\text { name }\end{array}$ & $\begin{array}{c}\text { Released } \\
\text { in year }\end{array}$ & Pedigree or origin \\
\hline 1 & Ylitornio & - & $\begin{array}{l}\text { landrace from northern Finland } \\
\text { selection from (White) Banner }\end{array}$ \\
2 & Wasa & - & $091-3 /$ Guldregn \\
3 & Jalostettu & 1921 & $091-3 /$ Guldregn \\
4 & maatiaiskaura & 1921 & $091-3 /$ Seger \\
5 & Osmo & 1922 & $091-3 /$ Guldregn \\
6 & Ksa & 1925 & Kerttu/Ta 036 \\
7 & Pellervo & 1935 & Ta 02272/Wasa \\
8 & Sisu & 1948 & Ta a3084/Ta 03370 \\
9 & Kyrö & 1959 & Eho/Sisu \\
10 & Hannes & 1964 & Pendek/Hja 24137 \\
11 & Hankkija-773 & 1973 & Hannes/Astor \\
\hline 12 & Hjan Valko & 1976 & \\
\hline 13 & Hjan Vouti & 1982 & \\
\hline
\end{tabular}

1 "Bred landrace" 
released in the course of 60 years. The breeding of oats was started in 1913, and the first varieties were released at the beginning of the 1920s.

Eleven of the total number of 16 varieties released by the Hankkija Plant Breeding Institute were included in the trial series in 1977-87. Those left out were Osmo II (1922), Pelso (1925), Louhi (1928), Tammi (1938), and Eho (1946).

During the long trial period, weather conditions varied greatly. In addition to cool and rainy growing seasons (for example, 1977, -79, -81 , and -87 ), there were also warm and favourable seasons (especially 1983). The trial series may be considered to represent well Finnish growing conditions as far as variation of weather is concerned.

The trials were planned by applying the method of partially balanced lattices, and each trial contained two replications. The plot size was $8 \mathrm{~m}^{2}$. Fertilization (Table 2) and plant protection conformed to current general recommendations for the cultivation of oats in southern Finland.

Observations about lodging and BYDV were made on the scale of 1 to 9 , in which 1 indicated the lowest degree of the trait (no lodging, no BYDV infection). The calculation was carried out with tenfold values, i.e. on the scale of 10 to 90 . Before treating the results, the grain yield, thousand kernel weight, hectolitre weight, and raw protein results were converted to correspond to a 15-per-cent moisture content.

To start with, the results of all traits were calculated for each individual trial, applying the Nearest Neighbor Analysis (WILKInSON et al. 1983, SchwARZBACH 1984), after which the combination of all 14 trials was calculated by the same method, using the annual results of the former. The calculations were based on the iterative calculation model presented by SCHWARZBACH (1984).

Table 2. Soil analysis and treatments in 14 trials of old varieties at Breeding Station Anttila (lat. $60^{\circ} 25^{\prime} \mathrm{N}$ ) and Breeding Station Nikkilä (lat. 61 $33^{\prime} \mathrm{N}$ ).

\begin{tabular}{|c|c|c|c|c|c|c|c|c|c|c|c|}
\hline \multirow{3}{*}{$\begin{array}{l}\text { Trial site } \\
\text { and year }\end{array}$} & \multirow{3}{*}{$\begin{array}{c}\text { Sowing } \\
\text { date } \\
\text { yymmdd }\end{array}$} & \multirow[t]{3}{*}{$\mathrm{PC}^{1}$} & \multirow[t]{3}{*}{$\mathrm{SC}^{2}$} & \multicolumn{5}{|c|}{ Soil analysis } & \multirow{2}{*}{\multicolumn{3}{|c|}{$\begin{array}{c}\text { Rate of } \\
\text { fertilizers } \\
\mathrm{kg} / \mathrm{ha}\end{array}$}} \\
\hline & & & & \multirow[t]{2}{*}{$\mathrm{pH}$} & \multicolumn{4}{|c|}{$\mathrm{mg} / \mathrm{l}$} & & & \\
\hline & & & & & $\mathrm{Ca}$ & $\mathrm{P}$ & K & $\mathrm{Mg}$ & $\mathrm{N}$ & $\mathrm{P}$ & K \\
\hline Nik 1977 & 770527 & 0 & 5 & 5.2 & 1500 & 12.5 & 195 & 210 & 120 & 26 & 50 \\
\hline Nik 1978 & 780518 & 7 & 5 & 6.2 & 2350 & 16.0 & 140 & 320 & 112 & 65 & 93 \\
\hline Nik 1979 & 790523 & 6 & 5 & 5.9 & 1500 & 10.0 & 153 & 140 & 105 & 61 & 87 \\
\hline Nik 1980 & 800514 & 12 & 5 & 6.0 & 1900 & 21.0 & 192 & 240 & 112 & 49 & 91 \\
\hline Nik 1981 & 810516 & 12 & 5 & 6.5 & 1850 & 17.0 & 95 & 310 & 112 & 49 & 91 \\
\hline Nik 1982 & 820511 & 12 & 5 & 6.4 & 1900 & 22.0 & 200 & 195 & 112 & 49 & 91 \\
\hline Ant 1983 & 830506 & 4 & 16 & 6.4 & 3000 & 18.0 & 120 & 720 & 110 & 22 & 44 \\
\hline Ant 1984 & 840517 & 4 & 12 & 6.3 & 2950 & 18.0 & 95 & 650 & 112 & 49 & 93 \\
\hline Nik 1984 & 840515 & 12 & 5 & 6.8 & 2250 & 23.0 & 175 & 140 & 110 & 22 & 44 \\
\hline Ant 1985 & 850521 & 4 & 12 & 6.1 & 2545 & 14.5 & 148 & 1030 & 110 & 55 & 127 \\
\hline Nik 1985 & 850521 & 12 & 5 & 5.9 & 1350 & 11.0 & 130 & 180 & 110 & 22 & 44 \\
\hline Ant 1986 & 860512 & 1 & 13 & 6.7 & 3200 & 11.0 & 139 & 595 & 102 & 68 & 136 \\
\hline Nik 1986 & 860523 & 12 & 5 & 6.1 & 1600 & 13.0 & 125 & 155 & 112 & 49 & 91 \\
\hline Ant 1987 & 870524 & 80 & 13 & 6.2 & 2750 & 13.0 & 135 & 670 & 112 & 49 & 91 \\
\hline
\end{tabular}

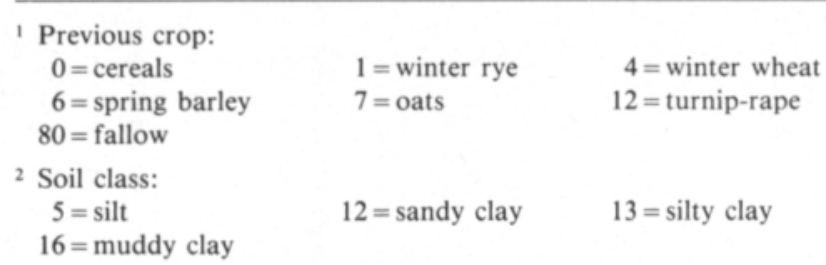




\section{Results}

The most important data on the combination of annual results are shown in Tables $3-5$. On the basis of this series of results, conclusions have also been presented about the progress made in different traits, as observed in varieties released during the period from 1921 to 1982.

\section{Yielding capacity}

Trial sites and trial years were very dominant factors in determining the yield, which is indicated by the fact that the variance component of trial sites was fivefold compared with the variance component of varieties. The lowest average yield, $290 \mathrm{~g} / \mathrm{m}^{2}$, was measured at Nikkilä in 1985, and the highest average yield, $714 \mathrm{~g} / \mathrm{m}^{2}$, at Anttila in 1983.
The interaction between environment and varieties, included now in the error term, was significant. The estimation of heritability, 0.42 , remained in the trial series at approximately the usual level. There were statistically significant differences in yield among the varieties.

The development of the yielding capacity of oat varieties during six decades is revealed clearly. When the average yield of the Hannes oat of the 1960s was chosen as the standard of comparison, the yields of the first varieties were almost 20 per cent lower. The yield of the Ylitornio land race was 10 per cent lower still. The youngest variety, Hankkijan Vouti, yielded 10 per cent more than Hannes and 35 per cent more than the weakest variety of the trial series, Pellervo, but as much as 51 per cent more than the Ylitornio land race. All these varieties belonged to the same group of earliness (Fig. 2).

Table 3. Results on yield and field observations in 1977-87. The varieties are in descending order of yield.

\begin{tabular}{|c|c|c|c|c|c|c|c|c|}
\hline \multicolumn{2}{|c|}{ Variety } & \multicolumn{2}{|c|}{ Yield $(15 \%)$} & \multirow{2}{*}{$\begin{array}{l}\text { Straw } \\
\text { length } \\
\mathrm{cm}\end{array}$} & \multirow{2}{*}{$\begin{array}{l}\text { Lodg- } \\
\text { ing } \\
\text { score } \\
10-90\end{array}$} & \multirow{2}{*}{$\begin{array}{c}\text { Head- } \\
\text { ing } \\
\text { d }\end{array}$} & \multirow{2}{*}{$\begin{array}{c}\text { Matu- } \\
\text { rity } \\
\text { d }\end{array}$} & \multirow{2}{*}{$\begin{array}{c}\text { BYDV } \\
\text { score } \\
10-90\end{array}$} \\
\hline $\begin{array}{l}\text { Age } \\
\text { rank }\end{array}$ & Name & $\mathrm{g} / \mathrm{m}^{2}$ & rel. & & & & & \\
\hline 13 & Hjan Vouti & 520 & 110 & 90 & 30 & 57 & 98 & 46 \\
\hline 10 & Hannes & 472 & 100 & 95 & 44 & 55 & 95 & 42 \\
\hline 11 & Hankkija-773 & 468 & 99 & 93 & 44 & 54 & 97 & 43 \\
\hline 8 & Sisu & 462 & 98 & 102 & 44 & 57 & 100 & 34 \\
\hline 12 & Hjan Valko & 433 & 92 & 91 & 32 & 53 & 96 & 42 \\
\hline 6 & Kytő & 422 & 89 & 97 & 52 & 53 & 96 & 47 \\
\hline 2 & Wasa & 420 & 89 & 101 & 60 & 57 & 101 & 40 \\
\hline 9 & Kyrő & 409 & 87 & 97 & 49 & 52 & 93 & 47 \\
\hline 4 & Osmo & 400 & 85 & 100 & 61 & 54 & 95 & 46 \\
\hline 3 & Jal. maat. & 393 & 83 & 98 & 57 & 55 & 98 & 43 \\
\hline 5 & Esa & 389 & 82 & 101 & 54 & 55 & 98 & 44 \\
\hline 7 & Pellervo & 377 & 80 & 108 & 54 & 56 & 98 & 49 \\
\hline 1 & Ylitornio & 344 & 73 & 117 & 66 & 60 & 97 & 41 \\
\hline & Mean & 423 & 90 & 100 & 50 & 56 & 97 & 43 \\
\hline & LSD $5 \%$ & 39 & 8 & 4 & 5 & 1 & 2 & 6 \\
\hline \multicolumn{9}{|c|}{ Components of variance: } \\
\hline \multicolumn{2}{|c|}{ Total } & 14764.86 & & 375.79 & 356.31 & 28.37 & 80.18 & 82.75 \\
\hline \multicolumn{2}{|c|}{ varieties } & 1994.86 & & 50.60 & 113.82 & 4.73 & 3.21 & 8.49 \\
\hline \multicolumn{2}{|c|}{ locations } & 10006.89 & & 299.12 & 197.01 & 22.24 & 70.09 & 37.85 \\
\hline \multicolumn{2}{|c|}{ error ${ }^{1}$} & 2763.11 & & 26.07 & 45.48 & 1.40 & 6.88 & 36.40 \\
\hline \multicolumn{2}{|c|}{ Std deviation } & 52.57 & & 5.11 & 6.74 & 1.18 & 2.62 & 6.03 \\
\hline \multicolumn{2}{|c|}{ Coef. of var. $(\%)$} & 12.44 & & 5.12 & 13.49 & 2.13 & 2.70 & 13.90 \\
\hline \multicolumn{2}{|c|}{ Heritability ${ }^{2}$} & 0.42 & & 0.66 & 0.71 & 0.77 & 0.32 & 0.19 \\
\hline
\end{tabular}

1 including interactions

${ }^{2}$ excluding variation of locations 
Table 4. Traits of yield and kernel quality in yield trials $1977-87$. The varieties in descending order of yield.

\begin{tabular}{|c|c|c|c|c|c|c|c|}
\hline \multicolumn{2}{|c|}{ Variety } & \multicolumn{2}{|c|}{ Yield $(15 \%)$} & \multirow{2}{*}{$\begin{array}{c}\text { TKW } \\
(15 \%) \\
\mathrm{g}\end{array}$} & \multirow{2}{*}{$\begin{array}{c}\text { HLW } \\
(15 \%) \\
\mathrm{kg} / \mathrm{hl}\end{array}$} & \multirow{2}{*}{$\begin{array}{c}\text { Husk- } \\
\text { cont. } \\
\%\end{array}$} & \multirow{2}{*}{$\begin{array}{c}\text { Crude } \\
\text { protein } \\
(15 \%) \\
\%\end{array}$} \\
\hline $\begin{array}{l}\text { Age } \\
\text { rank }\end{array}$ & Name & $\mathrm{g} / \mathrm{m}^{2}$ & rel. & & & & \\
\hline 13 & Hjan Vouti & 520 & 110 & 31.0 & 47.0 & 22.8 & 12.8 \\
\hline 10 & Hannes & 472 & 100 & 31.3 & 46.5 & 21.6 & 12.7 \\
\hline 11 & Hankkija-773 & 468 & 99 & 33.3 & 46.2 & 22.7 & 12.8 \\
\hline 8 & Sisu & 462 & 98 & 31.7 & 45.7 & 22.2 & 12.7 \\
\hline 12 & Hjan Valko & 433 & 92 & 35.0 & 45.7 & 22.2 & 13.0 \\
\hline 6 & Kytö & 422 & 89 & 31.4 & 46.3 & 24.2 & 13.3 \\
\hline 2 & Wasa & 420 & 89 & 33.8 & 47.9 & 23.8 & 12.9 \\
\hline 9 & Kyrö & 409 & 87 & 32.4 & 47.3 & 24.0 & 13.2 \\
\hline 4 & Osmo & 400 & 85 & 29.5 & 46.3 & 23.0 & 14.1 \\
\hline 3 & Jal. maat. & 393 & 83 & 31.0 & 47.2 & 23.3 & 13.0 \\
\hline 5 & Esa & 389 & 82 & 33.1 & 47.1 & 23.9 & 13.6 \\
\hline 7 & Pellervo & 377 & 80 & 33.3 & 47.7 & 22.8 & 13.9 \\
\hline \multirow[t]{3}{*}{1} & Ylitornio & 344 & 73 & 23.4 & 41.7 & 25.3 & 13.3 \\
\hline & Mean & 423 & 90 & 31.4 & 46.3 & 23.2 & 13.2 \\
\hline & LSD $5 \%$ & 39 & 8 & 1.3 & 1.7 & 0.9 & 0.5 \\
\hline \multicolumn{8}{|c|}{ Components of variance: } \\
\hline \multicolumn{2}{|c|}{ Total } & 14764.86 & & 13.35 & 20.43 & 3.60 & 3.34 \\
\hline \multicolumn{2}{|c|}{ varieties } & 1994.86 & & 8.06 & 2.14 & 0.93 & 0.16 \\
\hline \multicolumn{2}{|c|}{ locations } & 10006.89 & & 2.46 & 13.21 & 1.43 & 2.69 \\
\hline \multicolumn{2}{|c|}{ error ${ }^{1}$} & 2763.11 & & 2.83 & 5.08 & 1.24 & 0.48 \\
\hline \multicolumn{2}{|c|}{ Std deviation } & 52.57 & & 1.68 & 2.25 & 1.11 & 0.69 \\
\hline \multicolumn{2}{|c|}{ Coef. of var. (\%) } & 12.44 & & 5.36 & 4.87 & 4.80 & 5.25 \\
\hline \multicolumn{2}{|c|}{ Heritability $^{2}$} & 0.42 & & 0.74 & 0.30 & 0.43 & 0.25 \\
\hline
\end{tabular}

1 including interactions

2 excluding var. of locations

Table 5. Spearman's rank correlation test between age of variety and various traits in yield test series $1977-87$. (SNEDECOR 1956)

\begin{tabular}{lcl}
\hline Trait & $\begin{array}{c}\text { Rank correlation } \\
\text { for time trend }\end{array}$ & Significance \\
\hline Yielding potential & 0.76 & $1-\mathrm{P}<0.01$ \\
Straw length & -0.77 & $1-\mathrm{P}<0.01$ \\
Lodging ability & -0.94 & $1-\mathrm{P}<0.001$ \\
Time from sowing to heading & -0.31 & $\mathrm{~ns}$ \\
Time from sowing to maturity & -0.21 & $\mathrm{~ns}$ \\
Rate of BYDV-infected plants & -0.18 & $\mathrm{~ns}$ \\
Thousand kernel weight & 0.32 & $\mathrm{~ns}$ \\
Test weight & -0.14 & $\mathrm{~ns}$ \\
Husk content & -0.66 & $1-\mathrm{P}<0.05$ \\
Crude protein content & -0.50 & $\mathrm{~ns}$ \\
\hline
\end{tabular}

\section{Growing time}

The effect of trial sites and trial years on the determination of the number of growing days required for heading and yellow ripening was even greater than on the volume of yield. The variance component of trial sites was 4.7 -fold compared with the variety component when heading dates were studied. In ripening, the difference was even greater, for the trial site component was 21.8 -fold compared with the variety component.

The determination of both traits had been successful (variation coefficients 2.13 per cent 


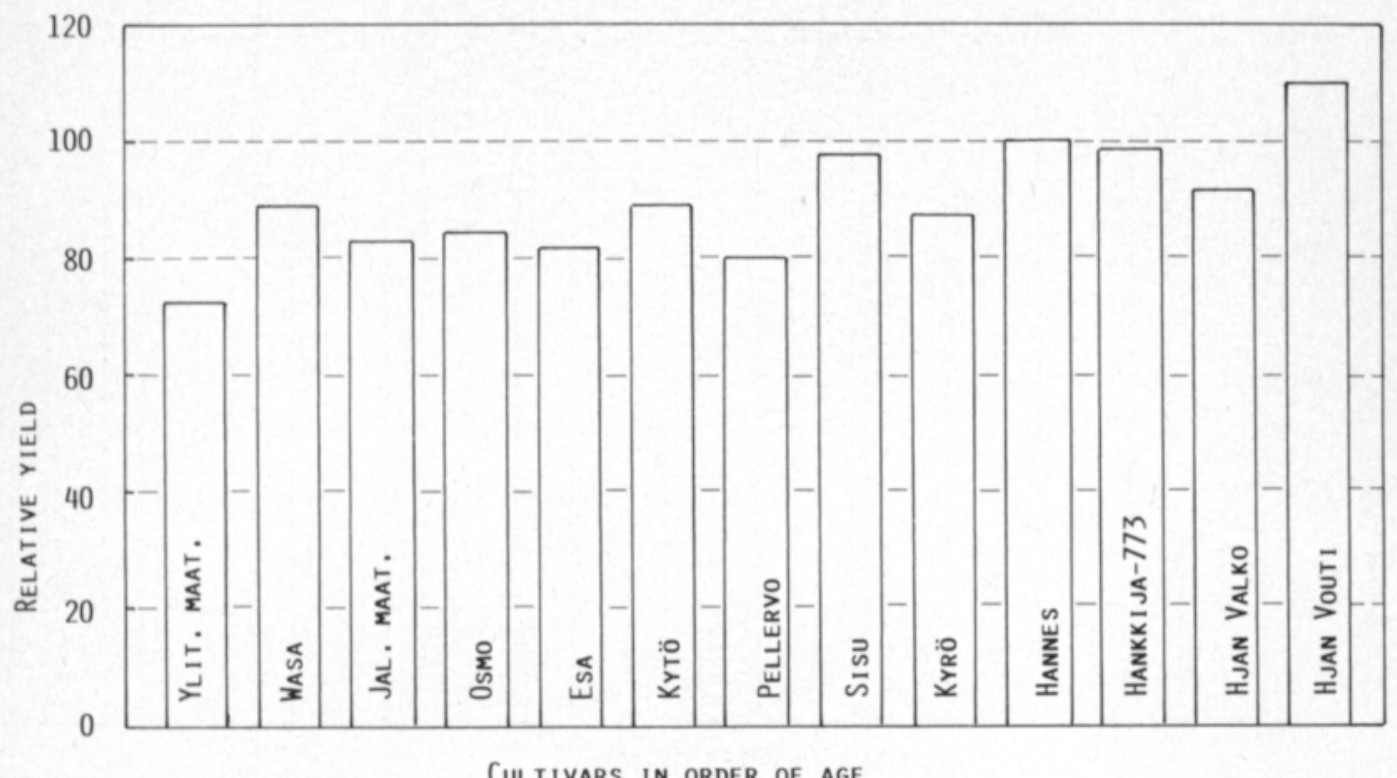

CUltivars in ORDER OF AGE

YIELD $\%$ OF HANNES

Fig. 2. The relative grain yield of varieties in $1977-87$ compared with Hannes. The varieties are presented in the order of their age.

and 2.70 per cent respectively) and the least significant difference was only one or two days. Heritability was estimated high for heading, 0.77 , and somewhat low for ripening, 0.32.

Significant differences in growing time were observed among the varieties as both heading and ripening were concerned. The old Wasa was latest on an average. Its growing time was 101 days. Sisu was almost equally late, 100 days. Kyrö ripened most rapidly; its growing time, 93 days, was one week shorter than those of the latest varieties.

The earliness of the varieties has remained approximately at the same level for the past decades, although there has been a tendency in breeding work to favour early material when developing cultivars (KIVI 1963, also). Early lines have, however, produced so much lower yields than late lines that they have not been released.

The ratio between heading date and ripening has also remained almost the same. While it for the first varieties took an average of 56 to 57 per cent of the total growing time to reach heading, the newest varieties have needed an average of 58 per cent for this. Thus, the proportion of time used for vegetative development has increased by a good one percentage unit.

\section{Straw traits}

In determining the length of straw, trial conditions have had an approximately sixfold effect compared with variety. The measuring results were reliable (variance coefficient 5.12 per cent), and the error remained small (LSD 5 per cent $=4 \mathrm{~cm}$ ). The heritability degree was fairly high, 0.66 , which indicates that there are good chances of heritability control of straw length.

There were significant differences among various varieties. Young varieties had in general shorter straws than old varieties. The variety with the shortest straw was Hankki- 


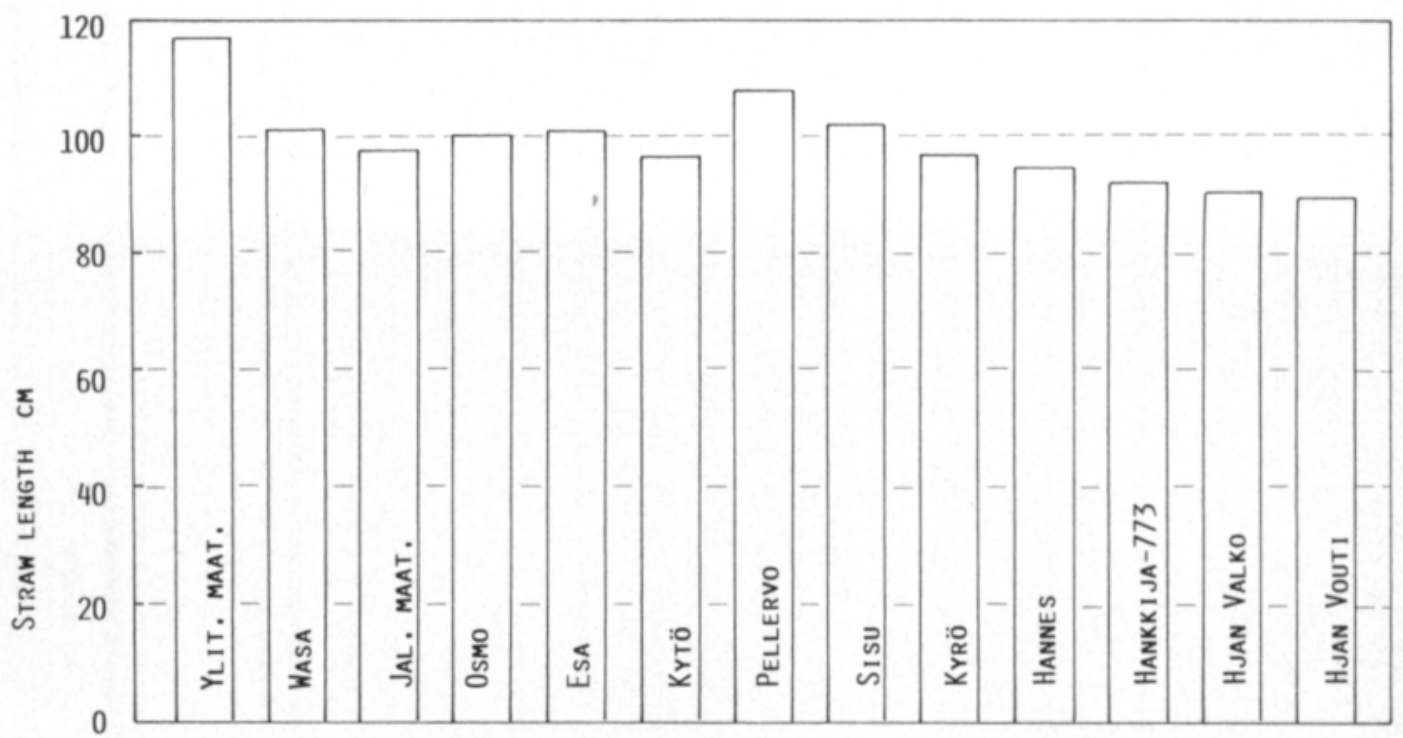

Cultivars IN ORDER OF AGE

\section{STRAW LENGTH CM}

Fig. 3. The mean straw length of varieties in 1977-87. The varieties are presented in the order of their age.

jan Vouti and the one with the longest straw, the Ylitornio land race (Fig. 3).

Significant variation could also be observed in straw stiffness among varieties representing different years. The least lodging variety was the youngest one (Hankkijan Vouti), and the most lodging varieties were the oldest ones (Jalostettu maatiainen, Osmo). The differences among variety groups representing different generations were statistically significant, which indicated that lodging became less when changing over to newer varieties (Fig. 4).

As far as straw stiffness was concerned, the variance component of site was twofold compared with the variety component. Thus, the ratio of the variance components was clearly lower than in the determination of yield or growing time. The reliability of the estimation of lodging was impeded by numerous factors, and therefore, owing to various combined effects, the trial error remained rather large. The high heritability estimation of 0.71 shows, however, that continuous progress is to be expected in breeding work.

\section{Resistance to plant diseases}

The resistance to plant diseases was not investigated separately in these trial series, but observations were made on the only BYDV appearing distinctly, and on that basis it is possible to make some conclusions.

The effect of site was 4.5 -fold compared with that of variety, and the variance component of the error remained large. The ranking order of varieties, according to degree of contamination, varied in different years. Perhaps it followed the variation in the point of time when aphids were spreading the diseases, wherefore the interaction contained in the trial error caused the trial error component to become so large. This made the comparison of varieties less reliable. The estimation of heritability, 0.19 , also remained low.

There were significant differences among the varieties, but they did not follow the age sequence. The smallest amount of BYD virus was observed in the late Sisu oat and the largest amount in Pellervo and the early Kyrö and Kytö oats. 


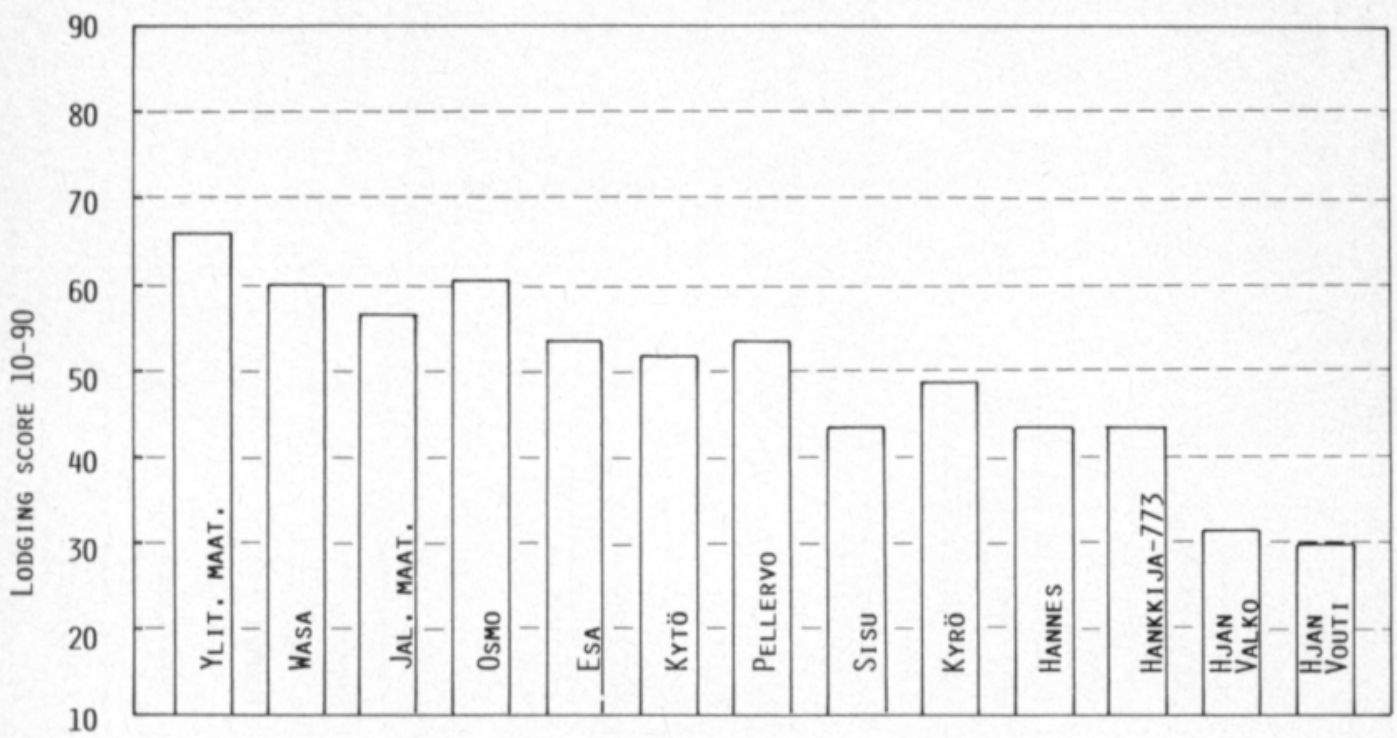

Cultivars in ORDER OF AgE

LoDGING $10-90$

Fig. 4. The mean lodging score of varieties in 1977-87. The varieties are presented in the order of their age.

\section{Grain size}

In the trials, the thousand kernel weight was controlled by variety at an approximately threefold force compared with location. The heritability degree of 0.74 was also high.

There were significant differences among the varieties, but no clear time trend could be observed in varieties of different age categories. The Ylitornio land race had by far the smallest grain size; its thousand kernel weight remained at $23.4 \mathrm{~g}$ on an average. The grain size of other varieties varied between $29.5 \mathrm{~g}$ (Osmo) and $35.0 \mathrm{~g}$ (Hankkijan Valko).

\section{Hectolitre weight}

As concerns determination of hectolitre weight, variety was of less significance than environment. The variance component indicating effect of trial sites and years was sixfold compared with the variety component. The trial error remained small and the reliability of hectolitre weight determination was good. On the basis of the heritability degree of 0.30 , the effect of genotype was weaker than normal.

There were significant differences among the varieties, but the Ylitornio land race deviated most clearly from the others. Its hectolitre weight remained at $41.7 \mathrm{~kg}$ on average, whereas with other treatments the figures varied from 45.7 to $47.9 \mathrm{~kg}$. Of all varieties, the Sisu and Hankkijan Valko oats produced the smallest hectolitre weights $(45.7 \mathrm{~kg})$, and the Pellervo and Kyrö oats, the highest (47.7 and $47.3 \mathrm{~kg}$ respectively). The hectolitre weight of the Wasa oat was still higher on average $(47.9 \mathrm{~kg})$, although this difference was not statistically significant.

In the light of this material, varieties representing different periods did not show any significant differences in hectolitre weight.

\section{Hull content}

When estimated on the basis of variance components, the effects of variety and trial sites on the hull content in oats were almost 


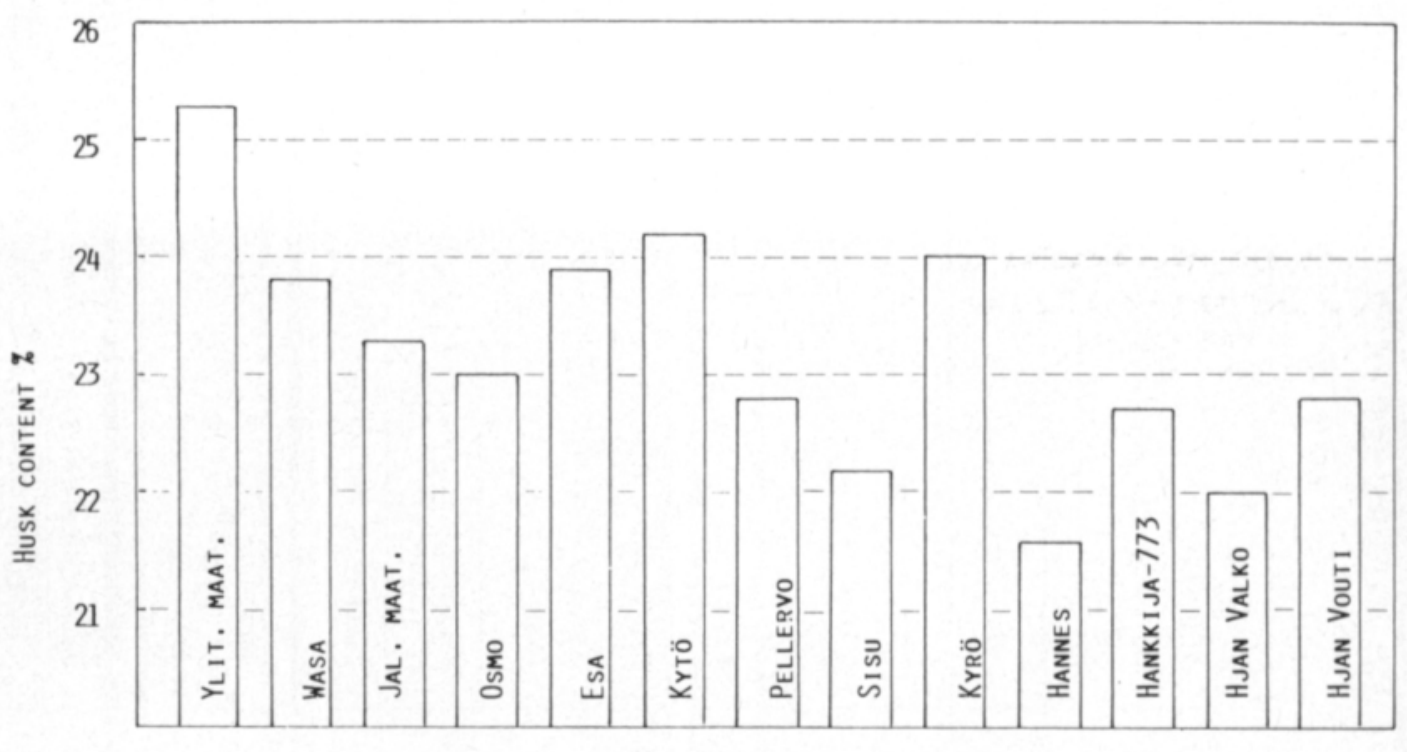

Cultivars in ORDER OF AGE

HUSK CONTENT \%

Fig. 5. The mean husk content of varieties in 1977-87. The varieties are presented in the order of their age.

equal. The determination of hull content was fairly reliable and the heritability degree of 0.43 was at a typical level.

There were statistically significant differences among the treatments, and also among variety groups representing different stages of life, differences were significant. The hull content was highest in the oldest material and lowest in varieties of recent decades (Fig. 5). The Ylitornio land race had the clearly highest hull content ( 25.3 per cent), followed by Kytö (24.2 per cent), Kyrö (24.0 per cent), and Esa (23.9 per cent). The lowest hull content was found in Hannes, 21.6 per cent, but Hankkijan Valko (22.0 per cent) and Sisu (22.2 per cent) also placed close to it.

\section{Crude protein content}

The estimation of crude protein content also turned fairly reliable (variation coefficient $=5.25$ per cent, LSD 5 per cent $=0.5$ percentage units). The influence of cultivation environment was about 17 -fold compared with the influence of variety, and the heritability degree, 0.25 , remained fairly low.

There were significant differences among varieties. The differences among variety groups representing different ages were also statistically significant; older varieties produced yields with a higher protein content than varieties grown in recent decades.

The highest protein contents were produced by Osmo, 14.1 per cent, and Pellervo, 13.9 per cent, the lowest by Hannes and Sisu, 12.7 per cent.

Measured by area units, however, new varieties produced clearly the most crude protein (Hankkijan Vouti $66.6 \mathrm{~g} / \mathrm{m}^{2}$, Hannes 59.9 $\mathrm{g} / \mathrm{m}^{2}$, and Hankkija-773 $59.9 \mathrm{~g} / \mathrm{m}^{2}$ ), and old varieties the least (Ylitornio land race 45.7 $\mathrm{g} / \mathrm{m}^{2}$, Jalostettu maatiaiskaura $51.1 \mathrm{~g} / \mathrm{m}^{2}$ ).

\section{Discussion of the results}

The six decades of breeding oats have changed the varieties to a great extent. There has been a distinct improvement in yielding 
capacity, straw length and stiffness, and the hull content of the kernels. The breeding work may be considered successful for the most important targets.

It is estimated that, during this time, the yielding ability of varieties has increased by approximately 40 per cent, the straw has shortened by some 20 per cent and become about twofold stiffer, and the hull content has decreased by some 2 percentage units, i.e. by 10 per cent. Along with higher yields, the crude protein yield per area unit has increased by 25 to 30 per cent.

AUFHAMmER's and FISCHBECK's (1964) series of trials with old oat varieties at the beginning of the 1960s gave similar results. According to their investigations, the breeding of oats had increased the yield by 40 to 50 per cent in 130 years. The new standard variety, NOS Weisshafer, was 48 per cent higher-yielding on average than the Nuremberg land race of 1832.

No similar trendlike change could be observed in this series of trials on the part of growing time, nor of grain size, hectolitre weight, crude protein content, or resistance to the BYD virus. It is true that, compared with the Ylitornio land race, the grain size and the hectolitre weight increased clearly, but fairly soon this trend stopped as the varieties established themselves at this higher level compared with the land races.

Aufhammer and Fischbeck (1964) also reported on an increase in the thousand kernel weight when changing over from old oat varieties to the present ones. The protein content of the grains, on the other hand, had dropped.

Although growing time plays an important role in Finnish cultivation conditions, no clear shift towards varieties with a shorter growing time was discernible in the results, and consequently no progress had been made in the breeding for earliness.

On the other hand, the growing time has not become longer either, although the high positive correlation between growing time and high yield, which is clearly discernible in Finnish conditions (REKUNEN 1970, 1976a, 1985a), could, in the efforts to seek high yields, easily lead to late varieties. Even more so as it, at the same time, has been possible to increase the yield to such a great extent.

Earlier, KIvı (1963) has also paid attention to the poor results of breeding for earliness, which plays such an important role in the breeding work.

From the relations between variance components, the conclusion could be made that environmental conditions clearly more than genotype determined all investigated traits, except the thousand kernel weight. The significance of the cultivation environment was especially great in the date of ripening and the determination of the crude protein content.

Estimates made of the heritability degree showed that the genotype was most dominantly revealed in the determination of straw length and stiffness, heading date and thousand kernel weight.

Observations most unreliable from a technical point of view were those made in connection with the scoring of BYDV and lodging, and the measuring of yielding capacity. Apart from trial errors, the main reason was the strong interaction between environment and genotype. Most accurate observations were made about growing time.

\section{References}

Aufhammer, G. \& Fischbeck, G. 1964. Ergebnisse von Gefäss- und Feldversuchen mit dem Nachbau keimfähiger Gersten- und Haferkörner aus dem Grundstein des 1832 errichteten Nurnberger Stadttheaters. Zeitschrift für Pflanzenzüchtung 51, 4: 354-373.

Huttunen, E. 1930. Kaura. Siemenjulkaisu 1930: $30-40$.

- 1935. Kaura. Siemenjulkaisu 1935: 26-37.

- 1946a. Kaura. Siemenjulkaisu 1946: 49-60.

- 1946b. Tammiston uusimmat kauppaan lasketut ja- 
losteet. Siemenjulkaisu 1946: 128-131.

- 1950. Sisukaura. Siemenjulkaisu 1950: 121-126.

- 1960a. Kaura. Siemenjulkaisu 1960: 55-63.

- 1960b. Kyrökaura. Siemenjulkaisu 1960: 199-201.

Kıvı, E. 1963. Domestic plant breeding for the improvement of spring cereal varieties in Finland. Acta Agr. Fenn. 100, 3: 1-37.

- 1965. Hanneskaura. Siemenjulkaisu 1965: 243-249.

ReKunEn, M. 1970. Kaura. Siemenjulkaisu 1970: 51-58.

- 1976a. Kaura. Siemenjulkaisu 1975: 50-59.

- 1976b. Kaura Hankkija - 773. Siemenjulkaisu 1975: 155-158.

- 1980. Hankkijan Valko-kaura. Siemenjulkaisu 1980: 125-128.

- 1985a. Kaura. Siemenjulkaisu 1985: 73-89.

- 1985b. Hankkijan Vouti-kaura. Siemenjulkaisu 1985: 156-161.

SAUL, J.O. 1920a. Jalostustyö Tammistossa kauraristeytyksillă ja koetuloksia niillä. Siemenjulkaisu 1920: 21-30.

- 1920b. Maatiaiskauroista ja niiden jalostuksesta Tammistossa. Siemenjulkaisu 1920: 90-95.

- 1920c. Tavallisimmista viljelyskasvilaaduista, niiden óminaisuuksista ja sopivaisuudesta meillă. Siemenjulkaisu 1920: 110-133.

- 1921a. Vertailevat kokeet Tammistossa v. 1920. Siemenjulkaisu 1921: 27-37.

- 1921b. Uusia kauralaatuja. Siemenjulkaisu 1921:
$59-63$.

- 1925a. Aikaisten kauralaatujen jalostustyöstä kasvinjalostuslaitoksellamme vv. 1913-1924. Siemenjulkaisu 1925: 89-95.

- 1925b. Laatuselitys kauppaan lasketuista Tammiston jalosteista. Siemenjulkaisu 1925: 110-114.

- 1925c. Uudet kaurajalosteet. Siemenjulkaisu 1925 : 115-116.

- 1930a. Ulkomaisista kauralaaduista ja niiden sopivaisuudesta Suomen oloihin. Siemenjulkaisu 1930: 159-173.

- 1930b. Selostus Tammiston uusimmista kauppaan lasketuista jalosteista. Siemenjulkaisu 1930: 180-183.

- 1935. Selostus Tammiston uusimmista kauppaan lasketuista jalosteista. Siemenjulkaisu 1935: 108-110.

SchwARZBACH, E., 1984: A new approach in the evaluation of field trials: The determination of the most likely genetic ranking of varieties. Vortr. Pflanzenzüchtung 6: 249-259.

SNEDECOR, G.W. 1956. Statistical Methods. Fifth edition. The Iowa State University Press 1956, 534 p.

VAlLe, O. 1938. Selostus Tammiston uusimmista kauppaan lasketuista jalosteista. Siemenjulkaisu 1938: $118-120$.

Wilkinson, G.N., ECKert, S.R., Hancock, T.W. and MAYo, O., 1983: Nearest Neighbour (NN) Analysis of Field Experiments. J.R. Statist. Soc.B. 45: 151-211.

\section{SELOSTUS}

\section{Kauranjalostuksen edistyminen}

\section{Matti Rekunen \\ Hankkijan kasvinjalostuslaitos, 04300 Hyrylä}

Vuosina 1977-87 selvitettiin kahdelle koepaikalle järjestetyin lajikekokein vanhojen kauralajikkeiden viljelyarvoa nykyisiin verraten. Kokeet sijaitsivat Hankkijan kasvinjalostuslaitoksen Nikkilän (lat. $61^{\circ} 33^{\prime} \mathrm{N}$ ) sekä Anttilan (lat. $60^{\circ} 25^{\prime} \mathrm{N}$ ) koetiloilla. Koejärjestely suoritettiin epătăydellisten lohkojen (Partially Balanced Lattices) menetelmien mukaisesti, kun taas tulokset ja niiden yhdistelmä laskettiin vierusanalyysiä (Nearest Neighbour Analysis) käyttăen. Kokeissa oli samanaikaisesti 11 laitoksen kauralajiketta vuosilta 1921-82 sekä vanha Ylitornion maatiaiskaura ja amerikkalaista alkuperäă oleva Wasa-kaura 1920-luvulta.

Aineiston esittely on koottu taulukkoon 1 ja koeolojen esittely taulukkoon 2 . Keskeiset tulokset esitelläăn taulukoissa 3-4 ja piirroksissa 1-5. Lajikkeiden ikäjärjes- tyksen ja ominaisuuden mukaisen paremmuusjärjestyksen keskinäinen riippuvuus käy ilmi taulukosta 5 .

Suoritetut kenttăkokeet osoittavat, ettă voimakasta jalostustyön edistymistă on havaittavissa satoisuuden lisăäntymisen, korren lyhentymisen, korrenlujuuden parantumisen ja kuoripitoisuuden alenemisen kautta. Uusimman lajikkeen, Hankkijan Voudin sato oli kokeissa keskimäärin $51 \%$ suurempi kuin Ylitornion maatiaiskauralla. Keskimăărăinen jalostustyön edistyminen vuosina 1921-82 oli näiden ominaisuuksien osalta: satoisuuden lisäys n. $40 \%$, korren lyhentyminen n. $20 \%$, lakoisuuden väheneminen puoleen sekä kuoripitoisuuden aleneminen n. 2 $\%$-yksiköllä.

Sităvastoin röyhylletulon ja tuleentumisen aikaisuudessa, tuhannenjyvånpainossa, hehtolitranpainossa, raaka- 
valkuaispitoisuudessa ja käăpiōkasvuviroosin (BYDV) kestävyydessă ei jatkuvaa edistymistä voitu osoittaa. Tuhannenjyvănpaino ja hehtolitranpaino olivat nousseet maatiaiskaurojen tasolta, mutta sen jälkeen kehitys pysăhtyi.

Tutkimuksessa vertailtiin myős genotyypin ja ympäristôvaikutusten keskinăisiă suuruussuhteita. Ympăristōtekijöillaa oli koesarjassa vähintaaăn viisinkertainen painoar- vo genotyyppiin nähden tuleentumiseen tarvittavan kasvuajan, raakavalkuaispitoisuuden, korrenpituuden, hehtolitranpainon ja jyväsadon määräytymisessä. Genotyyppi taas määräsi voimakkaimmin tuhannenjyvänpainoa, jolloin genotyypin varianssikomponentti oli kolminkertainen ympäristőn komponenttiin nähden. Heritabiliteettiarviot vaihtelivat koesarjassa 0.19:n (BYDV-infektio) ja 0.77:n (röyhylletulo) vălillă. 